\title{
KERAGAAN ALAT TANGKAP DAN JENIS IKAN DI PERAIRAN SUNGAI SIAK, PROVINSI RIAU
}

\author{
Khoirul Fatah dan Makri \\ Peneliti pada Balai Riset Perikanan Perairan Umum, Mariana-Palembang \\ Teregistrasi I tanggal: 10 Agustus 2009; Diterima setelah perbaikan tanggal: 20 Agustus 2009; \\ Disetujui terbit tanggal: 9 Nopember 2009
}

\begin{abstract}
ABSTRAK
Sungai Siak merupakan salah satu Sungai besar yang mengalir di Provinsi Riau yang memiliki banyak fungsi salah satu dari fungsi tersebut adalah usaha penangkapan ikan. Kegiatan penangkapan ikan di Sungai Siak menggunakan alat tangkap yang bersifat tradisional dan dilakukan secara kelompok atau perorangan. Penelitian ini bertujuan untuk mengetahui jumlah dan jenis alat tangkap, jenis ikan, kelimpahan relatif, dan keanekaragaman jenis ikan yang ada di perairan Sungai Siak pada tahun 2008. Pengambilan data dilakukan di perairan Sungai Siak mulai dari Kuala Tapung sampai Muara Mandau. Pengambilan data alat tangkap dilakukan terhadap nelayan yang sedang mengoperasikan alat tangkap tersebut, sedang pengambilan data jenis dan hasil tangkapan ikan dilakukan secara langsung di lapangan. Pengumpulan data bulanan jenis dan hasil tangkapan dibantu oleh nelayan setempat sebagai enumerator. Hasil penelitian menunjukan terdapat delapan jenis alat tangkap yang beroperasi di Sungai Siak mulai dari Kuala Tapung sampai Muara Mandau yaitu jaring, rawai, tajur, luka, pengilar, belad, dan jala. Alat tangkap jaring dan jala jumlah dan sebarannya paling banyak ditemukan di sepanjang Sungai Siak mulai dari Kuala Tapung sampai Muara Mandau, lalu disusul alat tangkap belad. Untuk jenis ikan ditemukan 60 jenis ikan yang tertangkap dari berbagai jenis alat tangkap, ikan tersebut berasal dari 12 famili dan satu jenis krustacea yaitu udang galah (Macrobrachium rosenbergii), dari 12 famili tersebut kelimpahan relatif didominansi oleh famili Cyprinidae dan Engraulidae baik pada bulan Juni, Agustus, dan Oktober. Jika dilihat dari nilai Indeks keanekaragaman pada beberapa stasiun Sungai Siak mempunyai nilai indeks berkisar antara $0,5-3,0$.
\end{abstract}

KATAKUNCI: $\quad$ alat tangkap, jenis ikan, Sungai Siak

ABSTRACT: Profile on fishing gears and fish at Siak River, Riau Province. By: Khoirul Fatah and Makri

Siak River one of the biggest river at Riau Province has a multipurpose function including fisheries. Fishing activity at the river used a traditional gear which was operated by individual or group fisherman. A study aimed to investigate number and type of fishing gears, fish species caught, relative abundance and fish diversity of the Siak River was conducted from Kuala Tapung until Muara Mandau in 2008. Data of fishing were collected from the fisherman operated the fishing gears. Monthly data on fish species caught and fish yield were collected directly by enumerator. Results of the study showed that eight kinds of fishing gears, namely gillnets, long line, hand line, traps (luka, pengilar, and belad), filtering device, and cast net were operated. The dominant fishing gear operated was gillnet and cast net and filtering device in the next. About sixty fish species from the twelve families and giant freshwaters prawn (Macrobrachium rosenbergii) were caught using those fishing gears. During June, August, and October, the relative abundance of the fish species was dominated by family of Cyprinidae and Engraulidae. The fish diversity index of the Siak River ranged from 0.5-3.0.

\section{KEYWORDS: $\quad$ fishing gears, fish species, Siak River}

\section{PENDAHULUAN}

Sungai adalah badan air yang kontinum dan merupakan salah satu tipe ekosistem perairan umum. Provinsi Riau memiliki empat sungai utama yaitu Sungai Siak, Rokan, Kampar, dan Indragiri. Sungai Siak merupakan salah satu sungai besar yang mengalir di Provinsi Riau yang memiliki banyak fungsi, antara lain sebagai sarana transportasi, sumber air minum, usaha budi daya, aktivitas penduduk seperti mandi cuci kakus, usaha penangkapan, media pembuangan limbah industri, dan lain-lain.

Sumber daya ikan di perairan Sungai Siak mempunyai posisi yang cukup strategis, hal ini mengingat ikan dalam kehidupan sehari-hari merupakan sumber protein hewani dan juga sebagai sumber pendapatan bagi masarakat sekitarnya. $\mathrm{Di}$ samping itu mengingat kondisi Sungai Siak saat ini telah mengalami kerusakan lingkungkan akibat 
adanya pencemaran, sedimentasi, dan pembakaran hutan yang mengakibatkan penurunan keanekaragaman hayati dan punahnya beberapa jenis ikan dan biota air. Oleh karena itu, sumber daya ikan yang saat ini tersisa di Sungai Siak tentunya terus dilestarikan agar tidak terjadinya kerusakanyang lebih parah lagi. Menurut Polnac \& Malvestuto, (1991). Ikan hidup dalam media air, maka kerusakan lingkungan perairan berakibat langsung terhadap kehidupan ikan.

Jenis ikan di perairan Sungai Siak nampaknya tidak berbeda jauh dengan jenis ikan yang ada di perairan Sungai Musi, hal ini menginggat kedua Sungai ini berada di daerah paparan Sunda dan bermuara di pantai timur Sumatera. Jenis ikan di bagian hulu mempunyai sifat berenang melawan arus (seperti ikan semah (Labeobarbus spp.) dan keragaman jenis sedikit, sedangkan di bagian tengah keragaman jenis ikan banyak. Jenis ikan di bagian hilir jenis ikan yang relatif tahan terhadap perubahan salinitas, seperti ikan eurihaline.

Intensitas penangkapan ikan di perairan sangat tergantung pada produktivitas alami yang sangat dipengaruhi kegiatan dan kondisi lingkungan darat di sekitarnya dan aktivitas ekonomi lain di perairan tersebut (King, 1998). Intensitas penangkapan, jumlah, dan jenis alat tangkap yang digunakan dan hasil tangkapan meningkat dengan berkurangnya ketinggian air. Pada umumnya alat tangkap ikan yang beroperasi di perairan umum (Sungai Siak) adalah alat tangkap yang tidak memerlukan banyak mesin atau peralatan canggih. Bahan-bahan alat tangkap tersebut sebagian besar adalah bahan-bahan yang tersedia di alam seperti bambu, kayu dan rotan, serta bahan tambahan yang mudah dibeli seperti kawat dan benang nilon untuk pembuat jaring. Berdasarkan pada hal di atas dilakukan penelitian inventarisasi alat tangkap dan jenis ikan di perairan Sungai Siak dengan tujuan untuk mengetahui jumlah dan jenis alat tangkap, jenis ikan, kelimpahan relatif, dan keanekaragaman jenis ikan yang ada di perairan Sungai Siak pada tahun 2008.

\section{BAHAN DAN METODE}

Penelitian ini bersifat survei lapangan dilakukan pada perairan Sungai Siak Provinsi Riau. Penelitian ini dilakukan mulai dari Kuala Tapung kiri dan kanan sampai Muara Mandau. Pengambilan contoh dilakukan empat kali setahun (bulan Maret, Juni, Agustus, dan Oktober 2008) di perairan Sungai Siak bagian hilir dengan penentuan stasiun ditentukan secara purposif (Gambar 1). Contoh yang dikumpulkan meliputi:

\section{Alat Tangkap}

Pengambilan data alat tangkap di Sungai Siak dilakuan dengan pengamatan langsung terhadap alat tangkap yang beroperasi meliputi, jumlah jenis, sebaran, cara operasi, deskripsi, dan jenis hasil tangkapan. Alat tangkap tersebut waktu operasi dicatat nama lokalnya dan nama ilmiahnya berdasarkan pada klasifikasi alat tangkap ikan menurut Brandt (1972); Welcome (1979).

\section{Jenis lkan}

Jenis ikan dikumpulkan dari hasil tangkapan nelayan dan pencatatan yang dilakukan oleh responden atau enumerator. Pemilihan enumerator dilakukan terhadap nelayan yang sudah berpengalaman lebih dari lima tahun dalam

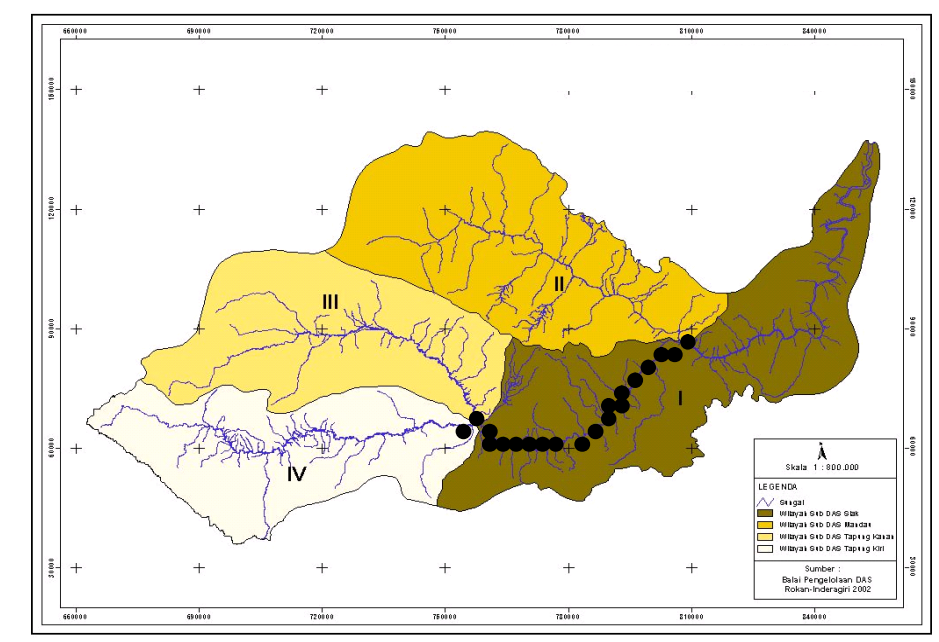

Gambar 1. Stasiun pengambilan contoh di Sungai Siak bagian hilir (point warna hitam). Figure 1. Sampling station at Siak River indicated by black point. 
menangkap ikan. Ikan yang didapat dari nelayan dikumpulkan dicatat nama lokalnya dan kemudian diawetkan dengan menggunakan formalin $10 \%$ dan dibawa ke laboratorium untuk diidentifikasi di Laboratorium dengan pedoman buku Weber \& De Beaufort (1916); Kotellat et al. (1993).

\section{HASIL DAN BAHASAN}

\section{Jumlah Jenis dan Sebaran Alat Tangkap}

Jumlah, jenis, dan cara operasi alat tangkap yang digunakan nelayan di Sungai Siak bervariasi dan tergantung pada jenis ikan yang akan di tangkap. Secara umum, cara operasi alat tangkap yang digunakan adalah memanfaatkan pola pergerakan ikan-ikan yang melakukan ruaya ataupun karena pergerakan air. Alat tangkap yang ditemukan saat penelitian berjumlah delapan jenis alat tangkap yaitu jaring tangsi hanyut (drift gillnet), jaring tangsi mantap (set gillnet), tajur, rawai, luka, pengilar, belad, dan jala. Dari hasil sensus alat tangkap di lapangan alat tangkap jaring dan jala mempunyai jumlah paling banyak ditemukan di sepanjang Sungai Siak mulai dari Kuala Tapung sampai Muara Mandau, lalu disusul alat tangkap belad (Tabel 1).

Tabel 1.

Table 1.

Jumlah dan jenis alat tangkap beroperasi di Sungai Siak, tahun 2008

Number and type of fishing gear operated at Siak River in 2008

\begin{tabular}{|c|c|c|c|c|c|c|c|c|c|c|c|c|c|c|c|c|c|c|c|c|c|c|}
\hline \multirow[b]{2}{*}{ No. } & \multirow{2}{*}{$\begin{array}{c}\text { Alat } \\
\text { Tangkap/ } \\
\text { Fishing } \\
\text { gears }\end{array}$} & \multicolumn{20}{|c|}{ Lokasi pengambilan contoh/Sampling station } & \multirow[b]{2}{*}{$\mathrm{Jml}$} \\
\hline & & 1 & 2 & 3 & 4 & 5 & 6 & 7 & 8 & 9 & 10 & 11 & 12 & 13 & 14 & 15 & 16 & 17 & 18 & 19 & 20 & \\
\hline 1. & Jaring & 5 & 3 & 4 & 5 & 6 & 4 & 4 & 5 & 2 & 3 & 5 & 4 & 3 & 5 & 5 & 5 & 6 & 5 & 3 & 2 & 84 \\
\hline 2. & Jala & 2 & 2 & 1 & 3 & 3 & 3 & 3 & 2 & 1 & 1 & 1 & 1 & 2 & 2 & 3 & 3 & 3 & 3 & 2 & 1 & 42 \\
\hline 3. & Tajur & 2 & 2 & 1 & 1 & 2 & 2 & 3 & 2 & 1 & 1 & 2 & 2 & 1 & 1 & 3 & 4 & 3 & 3 & 2 & 3 & 10 \\
\hline 4. & Rawai & 2 & 3 & 3 & 2 & 1 & 1 & & & & & & & & & & & & & & & 12 \\
\hline 5. & Luka & & & & 4 & 2 & 1 & & & & & & & & & & & & & & & 7 \\
\hline 6. & Pengilar & & & & 3 & 1 & & & & & & & & & & & & & & & & 4 \\
\hline 7. & Belad & & & & & & & & & & & & & & & & & & & & & 32 \\
\hline
\end{tabular}

Keterangan/Remarks:1. Tapung kanan; 2. Tapung kiri; 3. Refferensi Good; 4. Tiang Genting; 5. Refferensi Pasir keramat; 6. Leighton 2; 7. Refferensi Tampan; 8. PT. Non Siak; 9. Pelita Pantai; 10. Refferensi Pekanbaru; 11. Sungai Duku; 12. Pasifik; 13. Maredon; 14. Indahkiat; 15. Pelabuhan Tissu; 16. Refferensi Rasau Kuning; 17. Gasif; 18. Refferensi Gasip;19. Desa Segintil; Muara Sungai Mandau

Sebaran pengoperasian alat tangkap di perairan Sungai Siak (Gambar 1). Penangkapan ikan dengan mengunakan rawai dan tajur banyak dilakukan mulai dari stasiun Tapung Kiri dan Tapung Kanan sampai stasiun Refferensi Pasir Keramat, untuk alat tangkap bubu (pot trap) hanya dioperasikan di daerah Refferensi Good sampai Refferensi Tampan. Alat tangkap belad pengoperasiannya dilakukan mulai dari Stasiun Refferensi Tampan sampai Muara Mandau. Sedangkan alat tangkap jaring dan jala dioperasikan mulai dari Tapung Kiri dan Tapung Kanan sampai Muara Mandau.

\section{Deskripsi dan Cara Pengoperasian Alat Tangkap}

Dari hasil pengamatan di Sungai Siak mulai dari Tapung Kiri dan Tapung Kanan sampai Muara Mandau terlihat bahwa ada delapan jenis alat tangkap yang digunakan di perairan Sungai Siak. Cara pengoperasian alat tangkap ini oleh nelayan setempat tergantung sekali dengan pengaruh dinamika lingkungan seperti pengaruh pasang-surut dan musim. Dari delapan jenis alat tangkap yang ditemukan untuk klasifikasi dan habitat operasi dilihat pada Tabel 2.

Tabel 2. Jenis dan lokasi pengoperasian alat tangkap di perairan Sungai Siak Table 2. $\quad$ Fishing gear clasification and method at Siak River

\begin{tabular}{clll}
\hline No. & \multicolumn{1}{c}{ Nama lokal alat tangkap } & \multicolumn{1}{c}{$\begin{array}{c}\text { Klasifikasi Alat } \\
\text { Tangkap }\end{array}$} & \multicolumn{1}{c}{ Cara dan Iokasi pengoperasian } \\
\hline 1. & $\begin{array}{l}\text { Jaring: } \\
\text { Jaring tangsi hanyut } \\
\text { Jaring tangsi tetap }\end{array}$ & Gillnets & Memotong dan sejajar sungai \\
2. & Tajur & Hook and lines & Tepi sungai \\
3. & Rawai permukaan & Surface set long lines & Memotong dan sejajar sungai, Tepi sungai \\
4. & Luka & Box trap & Agak tepi sungai \\
5. & Pengilar & Trap (pots) & Tepi bersemak \\
6. & Belad & Beach barrier trap & Tepi sungai memanjang \\
7. & Jala & Cast nets & Bebas agak tepi \\
\hline
\end{tabular}




\section{Jaring}

Di perairan Sungai Siak ditemukan dua jenis jaring yaitu jaring tangsi hanyut dan tetap. Kedua alat tangkap ini beroperasi memotong atau sejajar sungai. Jaring tangsi hanyut dioperasi dengan cara dihanyutkan mengikuti arus air, pada waktu pasang jaring ini hanyut ke arah hulu, waktu surut jaring ini hanyut ke arah hilir sedangkan waktu operasi berkisar dari 45-60 menit. Jenis ikan dominan tertangkap yaitu ikan juaro, baung munti, dan coli. Untuk jaring tangsi tetap dioperasikan tidak mengikuti arus air, posisinya mantap di tempat. Kedua alat tersebut mulai dioperasikan pada waktu pergantian pasang dan pergantian surut, lama operasi 2-3 jam.

Kedua alat tangkap jaring tersebut mempunyai spesifikasi ukuran yang sama yaitu panjang berkisar 80-100 m, tinggi 5-6 m, dengan mata jaring berkisar 2,5-3 inci. Terbuat dari tali senar atau tali nylon yang mempunyai ukuran $4 \mathrm{~mm}$.

\section{Tajur dan Rawai}

Tajur dan rawai merupakan jenis alat tangkap yang bersifat pasif. Tajur terdiri atas mata pancing, tali pancing dari nylon, joran (tangkai) dari bambu atau batang kayu dan tali diberi pemberat atau pelampung. Rawai adalah sejenis pancing terdiri atas tali utama dengan panjang antara 50-100 cm dan jarak tali cabang satu dengan yang lainnya $1,5 \mathrm{~m}$, mempunyai mata pancing berkisar antara 20-30 buah, ukuran mata pancing no.15. Rawai dioperasikan di Sungai Siak pada waktu surut sedangkan tajur dioperasikan waktu pasang dan surut. Kedua alat tangkap ini dioperasikan di tepi sungai. Lamanya opersi berkisar antara 3,5-4 jam. Jenis ikan dominan tertangkap yaitu juaro dan patin, umpan yang digunakan buah pedada, jerohan ayam dan rang-rang atau keranggo. Ikan patin yang tertangkap dengan alat tangkap ini bobotnya berkisar antara $1-5 \mathrm{~kg}$. Alat tangkap tersebut di Sungai Siak banyak dijumpai di Tapung Kiri, Tapung Kanan, sampai Refferensi pasir keramat.

\section{Luka}

Luka (box trap) merupakan alat tangkap yang bersifat pasif, yang terbuat dari bilah-bilah bambu yang dijalin dengan rotan pada bagian depan berbentuk slinder dan bagian belakang berbentuk kerucut (Gambar 2). Bagian depan adalah mulut dilengkapi dengan injab, bagian belakang adalah pintu untuk mengeluarkan ikan. Panjang luka sekitar 2-3 m. Luka di Sungai Siak dioperasikan pada waktu air pasang dan musim penghujan, dioperasikan di pinggir-pinggir sungai pada kedalaman sekitar 1-2 m. Luka dibenamkan dalam perairan sungai ke dasar perairan dengan bagian mulut searah arus air. Jenis-jenis ikan yang tertangkap yaitu baung, baung munti, juaro, dan berbagai macam jenis-jenis ikan Cyprinidae.

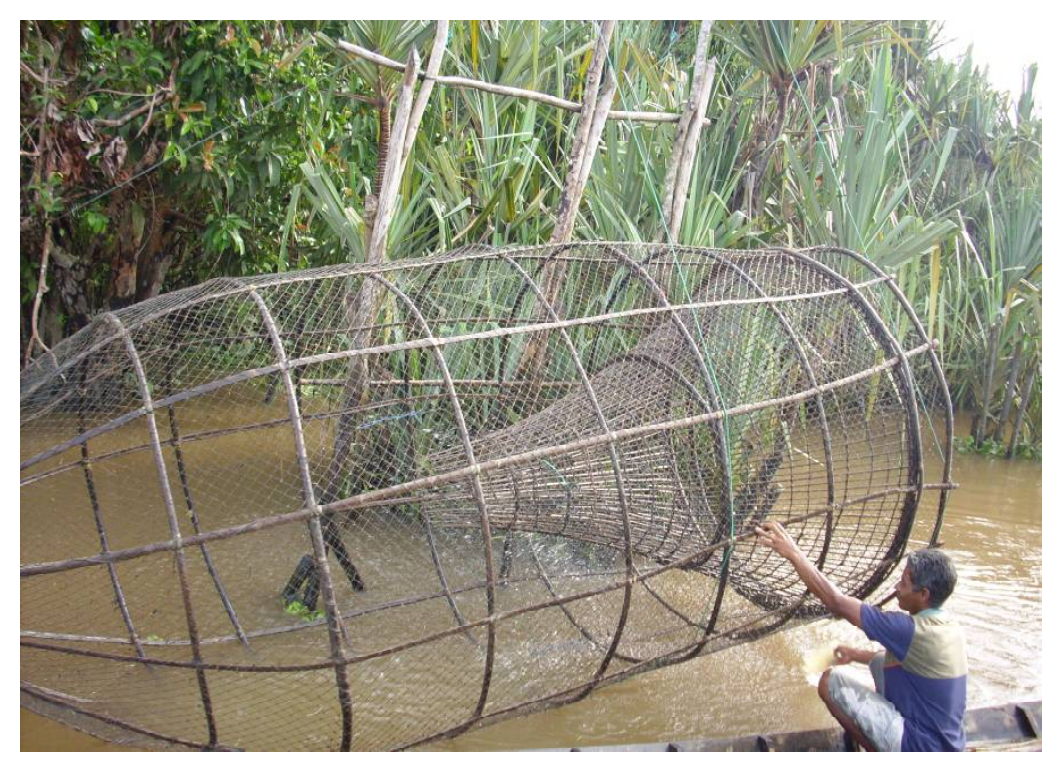

Gambar 2. Figure 2.
Alat tangkap luka di perairan Sungai Siak. Box trap at Siak River. 


\section{Pengilar Nilon}

Penggilar adalah perangkap yang bentuknya hampir menyerupai empat persegi panjang dengan ukuran beragam tergantung besar dan kecilnya pengilar (Gambar 3). Pengilar yang kecil mempunyai ukuran $30 \times 45 \times 50 \mathrm{~cm}$. Pengilar terbuat dari anyaman tali nilon dengan kerangka terbuat dari kayu. Pintu memanjang dari atas ke bawah dilengkapi dengan injab. Injab berfungsi untuk mencegah agar ikan yang sudah masuk ke dalam pengilar tidak dapat ke luar lagi. Alat tangkap ini bersifat pasif di operasikan di tepi sungai yang bersemak. Jenis ikan yang tertangkap di Sungai Siak dengan alat tangkap ini adalah lais, sihitam, lampam, tembakang, beringgit, gurame, janggut, dan lain-lain.

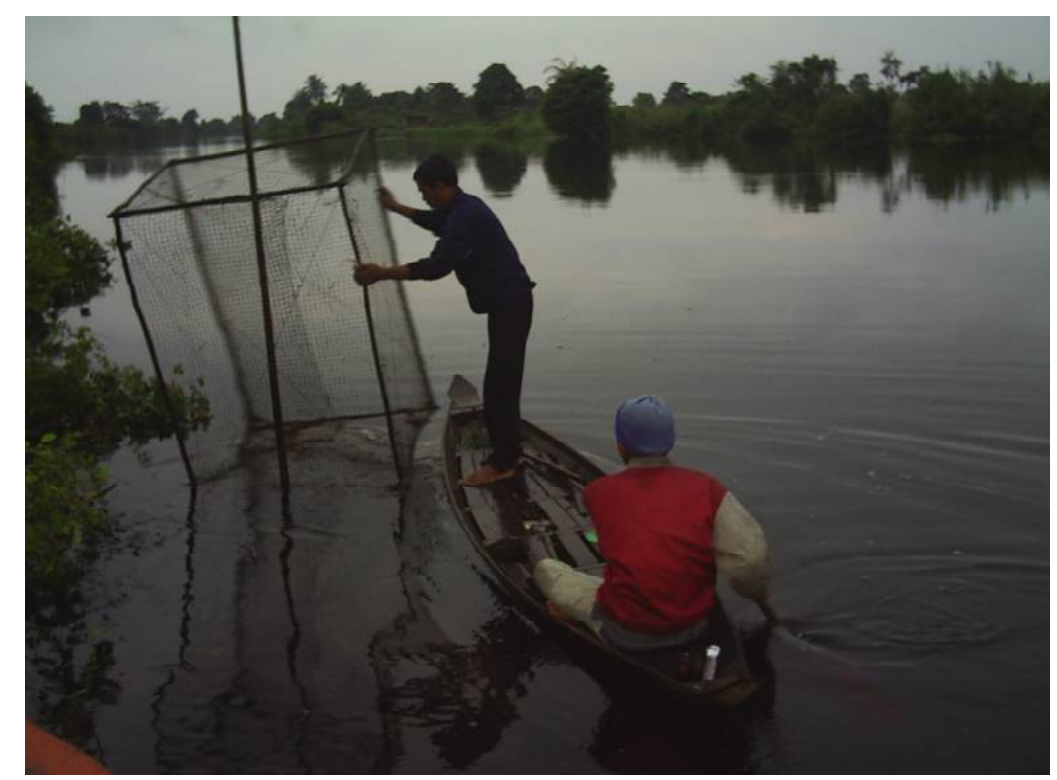

Gambar 3.

Operasional alat tangkap pengilar di perairan Sungai Siak.

Figure 3. Fishing operation of trap of Siak River.

\section{Belad}

Alat tangkap belad merupakan alat tangkap pasif yang dibuat dari bahan jaring dibantu dengan patik bambu atau kayu sebagai penopang sehingga mencapai ketinggian 2-2,5 m, panjang bervariasi 50$100 \mathrm{~m}$ dan tinggi 1,7-2 $\mathrm{m}$ dipasang sejajar garis pantai sungai. Jaring terbuat dari nilon ukuran $0,15 \mathrm{~mm}$ dan mata jaring 0,5 inci.

Pengoperasian alat tangkap belad (Gambar 4) sangat bergantung pada variasi tinggi air akibat pergerakan pasang surut air laut, di mana pada waktu air tinggi akibat pasang naik ikan dan udang yang melakukan ruaya untuk mencari makan di kawasan genangan dan akan kembali ke laut atau sungai akan masuk dalam jebakan alat tangkap belad, dan kemudian terkumpul pada bagian yang berfungsi sebagai kantong. Alat tangkap belad di Sungai Siak dioperasikan sepanjang tahun yang dilaksanakan 23 orang nelayan tergantung ukuran panjang belad. Jenis ikan yang tertangkap dengan alat tangkap belad adalah baung, tembakang, seluang, sepengkah, lais, dan lain-lain. 


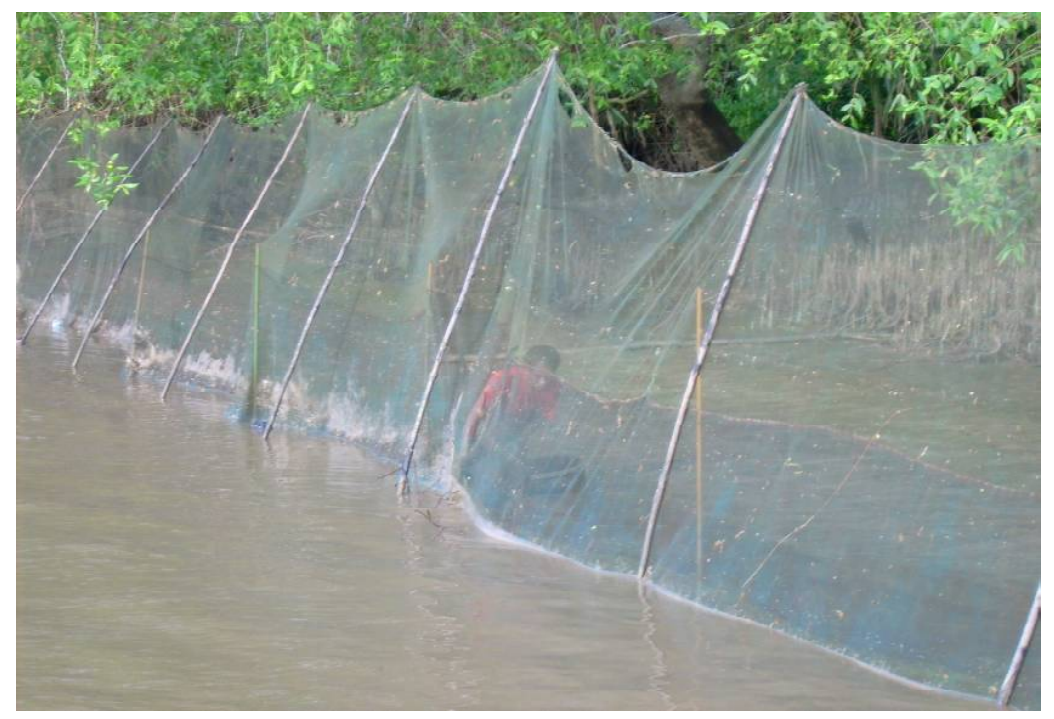

Gambar 4.

Figure 4.
Operasional alat tangkap belad di perairan Sungai Siak. Fishing operation of barrier trap at Siak River.
Jala

Alat tangkap jala merupakan alat tangkap yang bersifat aktif yang dibuat dari bahan senar dan mempunyai ukuran panjang $1,7 \mathrm{~m}$, mata jaring 1,5 inci. Alat tangkap jala di Sungai Siak dioperasikan di tepi Sungai. Jenis yang dominan tertangkap yaitu udang galah dan sedikit ikan ikut tertangkap.

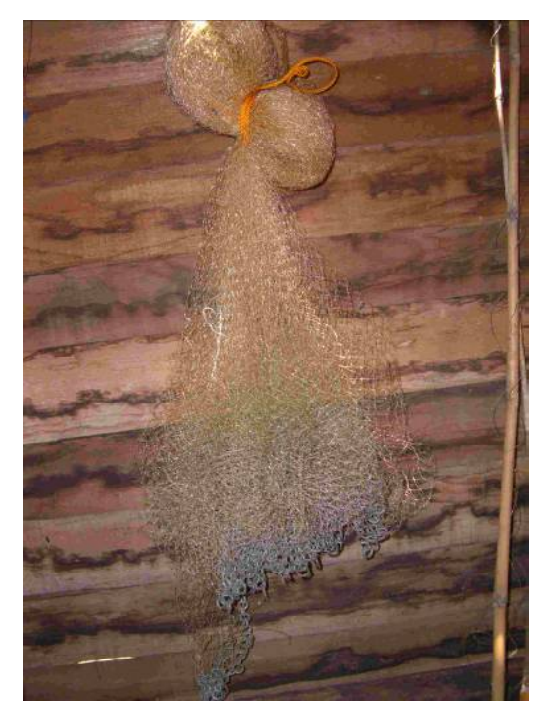

Gambar 5. Alat tangkap jala di Sungai Siak.

Figure 5. Cast net at Siak River.

\section{Jenis Ikan}

Hasil inventarisasi jenis ikan di perairan Sungai Siak mulai dari Kuala Tapung sampai Muara Mandau tahun 2008, didapatkan 60 jenis ikan yang berasal dari 12 famili dan satu jenis krustasea yaitu udang galah. Dari 12 famili tersebut kelimpahan relatif didominansi oleh famili Cyprinidae dan Engraulidae baik pada bulan Juni, Agustus, dan Oktober (Gambar 6). Sebagian besar genus dari famili Cyprinidae yang ditemukan tergolong Cyprinid berukuran kecil. Menurut Welcomme (2001), indikasi ini adanya tekanan lingkungan perairan adalah dominansi kelompok jenisjenis berukuran kecil dan kurang ekonomis. 


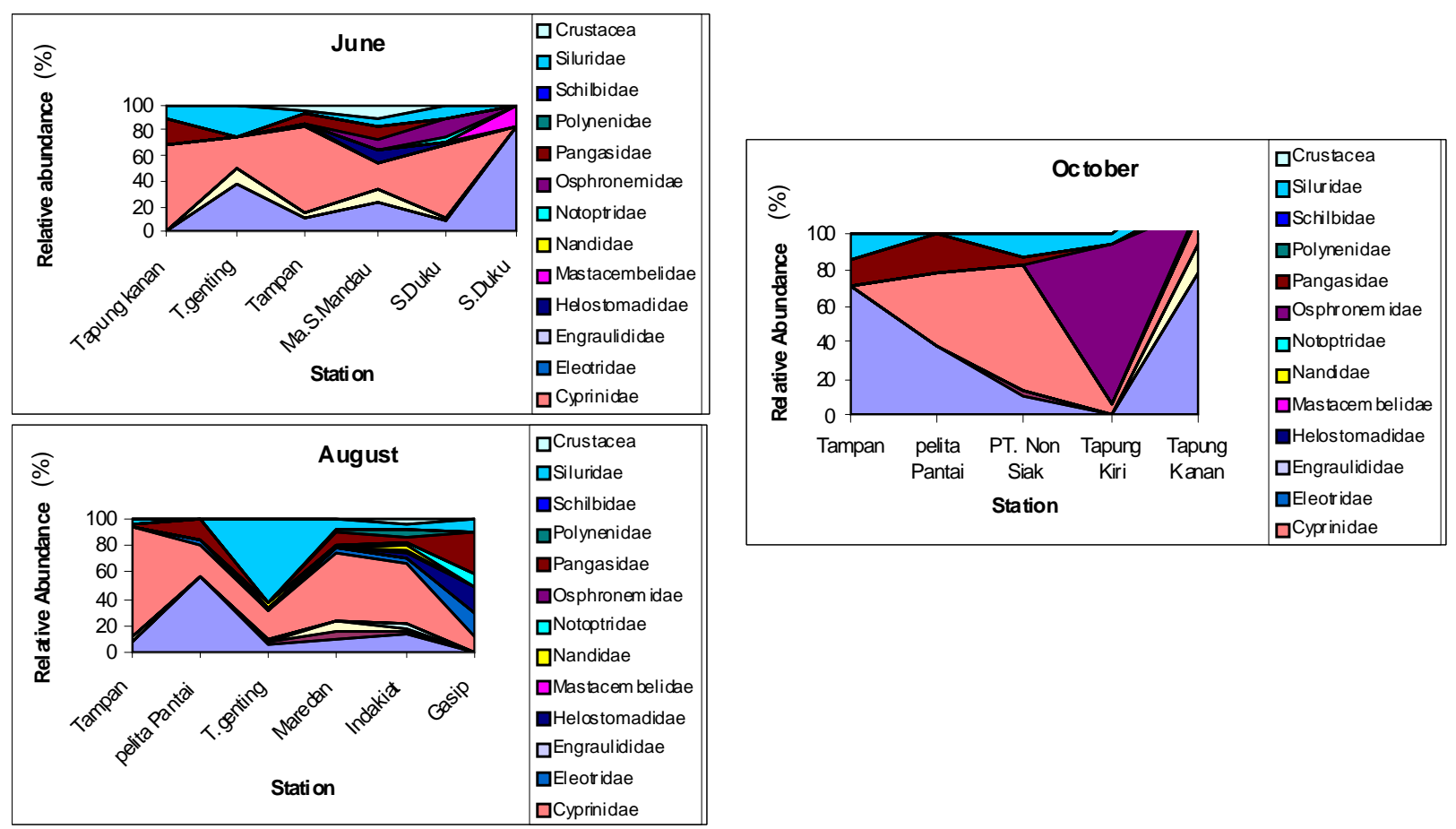

Gambar 6. Kelimpahan relatif ikan pada beberapa stasiun di Sungai Siak pada bulan Juni Agustus, dan Oktober 2008.

Figure 6. Relative abundance of fish based on station and month at Siak River in June, August, and October 2008.

Dilihat dari nilai indeks keanekaragaman pada beberapa stasiun Sungai Siak mempunyai nilai indeks berkisar dari 0,5-3 (Gambar 7). Indeks keanekaragaman yang tinggi mendekati nilai 3 ditemukan pada stasiun di sekitar Indah Kiat (Maredan, Indah Kiat, dan Pelabuhan Tisue Indah Kiat). Sedangkan yang terendah di stasiun Tapung
Kiri yaitu 0,5. Menurut Odum (1971) bila nilai keanekaragaman lebih kecil dari 1, maka keanekaragaman suatu organisme kecil, bila berada antara 1-3 maka keanekaragaman berada pada tingkat sedang, dan bila nilainya lebih besar dari 3 maka keanekaragaman jenis organisme termasuk tinggi.

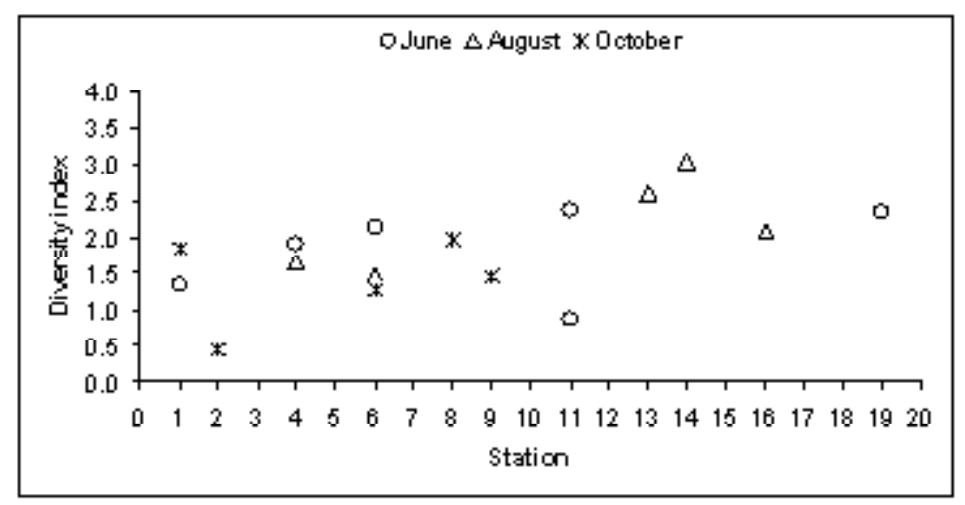

Gambar 7. Indeks keanekaragaman ikan pada beberapa stasiun di Sungai Siak pada bulan Juni, Agustus, dan Oktober 2008.

Figure 7. $\quad$ Diversity index of fish based on station and month at Siak River in 2008.

Keterangan/Remarks:1. Tapung kanan; 2. Tapung kiri; 3. Refferensi Good; 4. Tiang Genting; 5. Refferensi Pasir keramat; 6. Leighton 2; 7. Refferensi Tampan; 8. PT. Non Siak; 9. Pelita Pantai; 10. Refferensi Pekanbaru; 11. Sungai Duku; 12. Pasifik; 13. Maredon; 14. Indahkiat; 15. Pelabuhan Tissu; 16. Refferensi Rasau Kuning; 17. Gasif; 18. Refferensi Gasip;19. Desa Segintil; Muara Sungai Mandau 


\section{KESIMPULAN}

1. Terdapat delapan jenis alat tangkap yang beroperasi di Sungai Siak mulai dari Kuala Tapung sampai Muara Mandau yaitu jaring, rawai, tajur, luka, pengilar, belad, dan jala. Alat tangkap jaring dan jala jumlah paling banyak ditemukan di sepanjang Sungai Siak mulai dari Kuala Tapung sampai Muara Mandau, lalu disusul alat tangkap belad.

2. Dari hasil inventarisasi jenis ikan di Sungai Siak ditemukan 60 jenis ikan yang berasal dari 12 famili dan satu jenis krustacea yaitu udang galah dengan kelimpahan relatif didominansi oleh famili Cyprinidae dan Engraulidae.

3. Nilai indeks keanekaragaman ikan pada beberapa stasiun Sungai Siak mempunyai nilai indeks berkisar dari 0,5-3.

\section{DAFTAR PUSTAKA}

Brand, A. V. 1972. Revised and Enlarge Fish Catching Metods of the Word. Fishing News (books) Ltd. $340 \mathrm{pp}$.

Husnah, E. Prianto, K. Fatah, \& S. Kaban. 2008. Tingkat degradasi lingkungan perairan di Sungai Siak bagian hilir dengan bhenthic integrated biotic index. Laporan Teknis Balai Riset Perikanan Perairan Umum. Palembang. 60 pp.

Husnah, S. Nurdawati, \& E. Dharyati. 2005. Kegiatan penangkapan ikan di daerah aliran Sungai Musi bagian tengah. Prosiding Forum Perairan Umum 1. Balai Riset Perikanan Perairan Umum. Palembang. 347 pp.

King, M. 1998. Fisheries Bology, Assessment, and Management. Fishing News Books. 41 pp.

Kottelat, M., A. J. Whitten, S. N. Kartikasari, \& S. Wirjoatmodjo. 1993. Freshwater Fishes of Western Indonesia and Sulawesi (Ikan air tawar Indonesia bagian barat dan Sulawesi). Periplus EditionProyek EMDI. Jakarta.

Odum, E. P. 1971. Fundamental of Ecology. Third Edition. Philadelphia W. B. Saunders Company. $574 \mathrm{pp}$.

Polnac, R. B. \& Malvestuto. 1992. Biological and social economic conditions and management riverine fisheries resource on Musi and Kapuas River. Temu Karya IImiah Pengelolaan Sungai dan Perairan Umum bagi Perikanan di Pontianak. Tanggal 12-13 Maret 1991. USAID?FRDP. Puslitbang Perikanan > Jakarta. Pross/Puslitbang Perikanan/No 22/1992. 67-68.

Weber, M. \& De Beufort. 1916. The Fishes of the Indo-Australian Arcohipelago. E. J. Brill Itd. Leiden. Jilid 1-12.

Welcomme, R. L. 1979. Fisheries Ecology of Ploodplain Rivers. Longman. Inc. New York. 317 pp. 